\title{
VILLAGE FUND MANAGEMENT STRATEGY FORMULATION USING SOAR AND QPSM ANALYSIS IN KUPANG REGENCY
}

\author{
Ani Martini ${ }^{1}$ and Meirgin Yektris Killa ${ }^{2}$ \\ ${ }^{1}$ Faculty of Government Management, Institut Pemerintahan Dalam Negeri, Jl. Raya Bandung-Sumedang \\ KM. 21 Jatinangor, 456363. \\ ${ }^{2}$ Master Program, Institut Pemerintahan Dalam Negeri, Jl. Raya Bandung-Sumedang KM. 21 Jatinangor, 456363. \\ E-mail: animartini@ipdn.ac.id; meirginkilla.mk@gmail.com
}

\begin{abstract}
Implementing the Village Fund policy focusing on Baumata and Bokong Village, Taebenu District, Kupang Regency, has not provided the expected results. This study aims to formulate strategies for managing the Village Fund. The method used was a qualitative method with a descriptive approach. The research technique used is an interview with the Head and the Secretary of Village Government, Village Enterprises, Community Empowerment Agency, and people of the Villages. In proposing the Village Fund management strategy, SOAR and QPSM analysis tools are used. The results of the analysis formulate strategies that the Village Government can use in managing Village Funds, namely: (1) The Village Fund Budget is adequately managed to accelerate village development, (2) Firm action on the implementation of problematic activities according to regulations, (3) Existing human resources education and training are provided in the Village, and (4) Establishment of Village enterprises involving farmer groups and livestock groups.
\end{abstract}

Keywords: SOAR Analysis; Village Fund Policy; Village Fund Management Strategy.

\section{PERUMUSAN STRATEGI PENGELOLAAN DANA DESA DI KABUPATEN KUPANG MENGGUNAKAN ANALISIS SOAR DAN QPSM}

\begin{abstract}
ABSTRAK. Dalam pelaksanaan kebijakan Dana Desa di Desa Baumata dan Desa Bokong di Kecamatan Taebenu Kabupaten Kupang Provinsi NTT, belum mampu memberikan hasil sebagaimana diharapkan. Penelitian ini bertujuan untuk merumuskan strategi pengelolaan Dana Desa. Metode yang digunakan adalah metode kualitatif dengan pendekatan deskriptif. Teknik penelitian yang digunakan adalah wawancara dengan informan antara lain Kepala Kesa, Sekretaris Desa, Direktur BUMDes, Kepala Dinas Pemberdayaan Masyarakat Desa serta masyarakat desa yang wilayahnya menjadi obyek pembangunan dana desa. Dalam pengusulan strategi pengelolaan Dana Desa menggunakan alat analisis SOAR dan QPSM. Hasil analisis merumuskan strategi yang dapat digunakan oleh Pemerintah Desa dalam mengelola Dana Desa yaitu : (1) Anggaran Dana Desa dikelola dengan baik untuk percepatan pembangunan di desa, (2) Tindak tegas pelaksanaan kegiatan yang bermasalah sesuai dengan regulasi, (3) Sumber daya manusia yang ada di desa diberikan pendidikan dan pelatihan, serta (4) Pembentukan BUMDes yang melibatkan kelompok tani dan peternak.
\end{abstract}

Kata Kunci: Analisis SOAR; Kebijakan Dana Desa; Strategi Pengelolaan Dana Desa.

\section{INTRODUCTION}

Kupang Regency is one of the twenty-one regencies in East Nusa Tenggara, with an area of $5,298.13 \mathrm{~km}^{2}$ and a population of 387,479 people with a total of 24 sub-districts with 17 sub-districts and 160 villages (BPS, 2019a). Kupang Regency has received Village Funds for its 160 villages since 2015, the Vice Regent Head of Kupang, Jerry Manafe noted that 129 out of 160 villages had not submitted accountability reports for the first and second stages of the 2019 Village Fund, this will affect the third stage of disbursement and will undoubtedly receive sanctions in the form of not receiving the third stage of village funds (Billiocta, 2019).

In 2017 the Village Fund in Kupang Regency amounted to Rp.128,306,880 million with an average income per Village of Rp.801,918 million in 2018 it was Rp.135,628,602 million with a village income of Rp.849,013 million and increased in 2019 with the number of transfers to Kupang Regency amounted to Rp. $165,133,602$ million, and the average income per Village reached Rp. 1,032,082 million, based on the data, it was concluded that the Village Fund in Kupang Regency from 2017 to 2019 had reached Rp. 429,122,688 million with an average income per Village of Rp. 2,683,013 million. The number of Village Funds that continue to grow every year should build and provide a change in Kupang Regency.

The public welfare indicator publication explains the socio-economic conditions and welfare of the people of Kupang Regency obtained through a national socio-economic survey in Kupang Regency that as of September 2018, as many as $39 \%$ of the people of Kupang Regency experienced health complaints of them only $64.03 \%$ had health insurance. In addition, as of August 13, 2019, as many as 4,750 children in Kupang Regency were stunted due to chronic malnutrition. This condition caused the children's bodies in Kupang Regency to 
be shorter than their age, or more commonly known as Stunting. $8 \%$ of the population aged over 15 years and over are still unable to read and write (Jahang, 2019).

Taebenu sub-district is one of the sub-districts directly adjacent to the city of Kupang as the provincial capital, with an area of $106.89 \mathrm{~km} 2$ with a total of 8 villages, with five villages in the selfhelp village category and three self-help villages in the category (BPS, 2019b). Villages with the selfemployment category consist of Oeletsala Village, Kuaklalo Village, Bokong Village, East Baumata Village, and Oeltua Village, the largest being Bokong Village with an area of $45.63 \mathrm{~km} 2$ with a percentage of the area covering $43.69 \%$. For villages in the selfhelp category, consisting of Baumata Village, West Baumata Village, and North Baumata Village, and villages with self-help categories, the largest area is Baumata Village with an area of $12.00 \mathrm{~km} 2$ with a percentage of $11.49 \%$ area. (BPS, 2019b).

Seeing the amount of Village Fund allocations each year from the government, the government should have been able to have an impact in helping to overcome problems in villages in the Taebenu District Area such as improving public services, alleviating poverty, advancing the village economy, overcoming development gaps between villages, and strengthening rural communities as a development subject (Faisal, 2018). However, in practice, it has not had a significant impact on community development and empowerment in Taebenu District, Kupang Regency. Infrastructure is the government's concern in the development process, as expressed by the President of the Republic of Indonesia, Joko Widodo, that there is not a single developed country in the world that is not supported by good infrastructure. It can be concluded that every developed country has a good infrastructure. According to him, the infrastructure can be from village roads, village bridges, small ports, large ports, airports or airports, power plants, and communications. This infrastructure is what makes us compete, win with other countries (Prabowo, 2019).

The location of Taebenu District is directly adjacent to Kupang City, which is the capital of East Nusa Tenggara Province, as the center of government, starting from this Taebenu District should be more advanced than other Districts in Kupang Regency in terms of road access and the ability of the Taebenu sub-District Government to absorb available information. However, in fact, eight villages in the Taebenu sub-district are still in the developing and underdeveloped category. Taebenu District consists of 3 villages with developing categories, namely
Oeltua Village, Baumata Village, and West Baumata Village, and five villages with underdeveloped categories, namely East Baumata Village, North Baumata, Oeletsala Village, Kuaklalo Village and Bokong Village, North Baumata Village. Bokong is a village in the category of underdeveloped Village with the lowest score of 0.5007 , and for the Village with the category of developing Village, the highest score is Baumata Village with a score of 0.6560 . The Village directly adjacent to the central government is Baumata Village, and the farthest Village is Bokong Village.

The Ministry of Village, Local Underdeveloped Region, and Transmigration issued a regulation regarding priority use of village funds number 16 of 2018 concerning Priority for the use of Village Funds in 2019. It was explained that Village Funds sourced from the State Revenue and Expenditure Budget could be used for village infrastructure development such as village roads to facilitate village access.

There has been no change in the construction of health facilities in the last three years, namely 2016, 2017, and 2018 for butt village and Baumata village. Data in Kupang Regency shows that the number of people experiencing chronic malnutrition is still high. Still, the villages in the use of the budget have not established additional health facilities to support the community, in this case, we can see that from 2016 there was only one PHC for eight villages in the Taebenu sub-district, which is located in Baumata Village. The number of sub-health centers only saw one auxiliary health center, namely in Baumata Timur village in 2017. There was one additional health center, and for IHC there was no increase.

Government Regulation of the Republic of Indonesia, Number 60 of 2014 concerning Village, Funds Sourced from the State Revenue and Expenditure Budget, Chapter V with the title Usage explains that Village Funds are used to finance government administration development, community and community empowerment. In paragraph 2 , it is stated that the Village Fund, as referred to in paragraph 1 , is prioritized to finance development and community empowerment. Government regulation regulate that the budget sourced from the Village Fund program is utilized by the Baumata village in financing activities in the field of village development and village empowerment. In contrast, development activities include organizing IHC, providing additional food, road paving activities, gate construction activities, and public latrine maintenance activities. Activities in the village empowerment field include exercises to increase livestock production (production/ management equipment), training and counselling 
on women's empowerment, and developing smallscale industries at the village level (Accountability Report on the implementation of the Village Budget of Desa Baumata, 2019).

Based on the Accountability Report, the use of the Village Fund in Tabaenu Village is used for the implementation of activities in the field of village development, community development, and community empowerment. Activities in the field of village development include the management of PAUD / TK / TPA / TPQ / Madrasah, construction/ rehabilitation/improvement/procurement of village office facilities and infrastructure, implementation of IHC (supplementary food), health education and training (for the community), road paving hamlet II, paving the village road $\mathrm{V}$, construction/rehabilitation/ improvement of clean water sources, organizing village public information (posters, billboards, etc.). Activities in community development include strengthening and improving security personnel, managing youth training at the village level, and fostering community institutions. Community empowerment activities include increasing food crop production (agricultural production tools), strengthening village-level food security (village barns), construction of tertiary/simple irrigation channels, capacity building for village officials, capacity building for BPD, management of community health service activities, training for Village Enterprises management. and management of services and small industries in the form of furniture (Accountability Report of the Village Revenue and Expendture Budget Implementation Baumata Village, 2019). Based on the table above, we can also see that in the preparation of activity programs in Bokong Village, there is still a lack of activity programs in the field of community development.

Based on the description of the problem of implementing village fund management policies in Baumata and Bokong Village above, it can be formulated research problems, namely how to formulate village fund management strategies? Thus, this research aims to formulate the strategy of village fund management in Kupang Regency with using SOAR and QPSM.

\section{METHOD}

The research method used in this research is descriptive qualitative research with data analysis using an inductive approach. Because in this study, the researcher focuses more on describing or describing events that occur in the field systematically, logically and objectively, so they must be able to understand every fact that happens and solve existing problems using the scientific method. The discussion of the main issues is described in an analytical descriptive manner. Descriptive means describing systematically, factually and accurately the characteristics of the object under study, namely the evaluation of the Village Fund policy in Taebenu District. While analytical means that the researcher analyzes the results of the research findings based on the knowledge of the understood theory.

Furthermore, to answer the second problem formulation, the author uses SOAR analysis (strength, opportunity, aspiration and result) derived from the Appreciative Inquiry (AI) approach, which was developed by David Cooperrider to help organizations achieve their dreams which focuses on identifying and building strengths. And opportunities from problems, rather than weaknesses and threats. In this approach, the focus is on the organization's strengths and shared values and vision (Sprangel et al., 2011; Stavros \& Malone, 2015). In supporting the process of finding the right strategy to be applied by the Village Government in managing the Village Fund, the author conducts data management using the Quantitative Strategic Planning Matrix (QPSM) (David, 2017).

\section{RESULT AND DISCUSSION}

The Village Fund Program policy since 2015 places the Village as the spearhead of development and community empowerment. Villages are given adequate authority and sources of funds to manage their potential. The evaluation results from 2015 to 2018 have proven that the Village Fund has produced facilities/infrastructure that is beneficial to the people of Indonesia. However, its implementation in Taebenu District still has not had a good enough impact on development and community empowerment.

The results of the evaluation of the implementation of the Village Fund Program policy in Taebenu District, showed that of the two villages analyzed by the author, namely Baumata Village and Bokong Village, the implementation of activities in Baumata Village using budget sources The 2019 Village Fund has not been implemented as expected. Based on the analysis that has been carried out using the policy evaluation theory, as follows a) effectiveness; b) efficiency; c) adequacy; d) equity; e) responsiveness; f) accuracy (Dunn, 1994). Based on the above discussion, it can be seen that the results of the evaluation of the Village Fund policy in Baumata Village and Bokong Village, Taebenu District, Kupang Regency show problems that occur 
in Baumata Village, facing this the author proposes a strategy that the Baumata Village Government can do in managing the existing Village Funds with the SOAR strategy, which begins with internal factor analysis (Cole et al., 2019; Stavros \& Malone, 2015).

\section{Internal Factor Evaluation (IFE) Analysis}

IFE analysis is the result of identifying internal factors in the form of strengths and opportunities (Stavros \& Malone, 2015). The strength factors that can be identified are the existence of a budget for the field of development and community empowerment, The presence of regulations that regulate the Priority of using the Village Fund in one year running, The existence of human resources who can manage the Village Fund (Susilowati et al., 2019), There is a budget allocation for improving the welfare of rural communities through village enterprises, the positive response of the village community to the Village Fund policy and the existence of village officials to manage the Village Fund (Ali et al., 2019; Ommani, 2011).

Internal factors in the form of opportunities can be identified in the form of budget sources other than Village Funds that can be used for community development and empowerment, the implementation of binding activities, activities oriented to increasing existing resources in the Village, the Establishment of village enterprises, the use of village communities in managing Village Funds, and proposals to accelerate the making of regulations that regulate the recruitment of new village officials (Ommani, 2011). (Table 2.)

Based on the results of calculations with the IFE matrix, a score of 112 was obtained. With a maximum weight of 1.00 . The highest weight is found on 4 points of internal factors, and the lowest weight is on 4 points of internal factors.
The score ranged between 1.0 as the low point, the highest point was 4.0, and the average score was 2.5. A score below 2.5 describes a weak organizational condition internally, while a score above 2.5 describes a solid administrative situation. The total weight of the IFE matrix shows the number 3,295, which characterizes Baumata Village internally as quite strong.

\section{External Factor Evaluation (EFE) Analysis}

Furthermore, external factors or the EFE (External Factor Evaluation) matrix is carried out. This analysis is based on the aspirations and the results to be achieved. External factors in the form of aspirations that can be identified are in the form of accelerated development and improvement of village facilities, firm action against the implementation of activities that are not running properly, education and training for resources that manage the Village Fund and implementation of studies appeal to villages that have been included in the independent village category, Establishment of Village enterprises by involving farmer groups and livestock groups to improve the welfare of rural communities (suppliers of seeds and sales of produce) (Ngadisah \& Alma'arif, 2019), Involvement of all levels of society in carrying out activities in the Village, and Increasing the number of village officials according to with the workload in the Village and the required scientific fields (Cole et al., 2018; McLean, 2017).

Furthermore, External factors in the form of what results to be achieved in the management of Village Funds that can be identified are in the form of accelerated development and empowerment of rural communities, proper management of village funds following policy expectations, talented

Table 1. Analysis Using IFE Matrix

\begin{tabular}{|c|c|c|c|c|c|c|c|c|c|c|c|c|c|}
\hline \multirow{2}{*}{\multicolumn{2}{|c|}{$\begin{array}{c}\text { Internal } \\
\text { Factor } \\
\text { IF }_{1} \\
\end{array}$}} & \multicolumn{8}{|c|}{ HORIZONTAL } & \multirow{2}{*}{ Total } & \multirow{2}{*}{ Weight } & \multirow{2}{*}{ Rating } & \multirow{2}{*}{ Scores } \\
\hline & & $\mathrm{IF}_{2}$ & $\mathrm{IF}_{3}$ & $\mathrm{IF}_{4}$ & $\mathrm{IF}_{5}$ & $\mathrm{IF}_{6}$ & $\mathrm{IF}_{7}$ & $\mathrm{IF}_{8}$ & & & & & \\
\hline \multirow{8}{*}{ 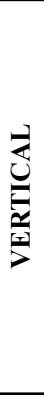 } & $\mathbf{I F}_{1}$ & $\mathrm{X}$ & 3 & 2 & 1 & 1 & 2 & 2 & 1 & 12 & 0,107 & 4 & 0,429 \\
\hline & $\mathbf{I F}_{2}$ & 1 & $\mathrm{X}$ & 1 & 1 & 2 & 2 & 1 & 1 & 9 & 0,080 & 4 & 0,321 \\
\hline & $\mathrm{IF}_{3}$ & 2 & 3 & $\mathrm{X}$ & 2 & 1 & 2 & 3 & 1 & 14 & 0,125 & 2 & 0,250 \\
\hline & $\mathrm{IF}_{4}$ & 3 & 3 & 2 & $\mathrm{X}$ & 3 & 2 & 3 & 1 & 17 & 0,152 & 3 & 0,455 \\
\hline & $\mathrm{IF}_{5}$ & 3 & 2 & 3 & 1 & $\mathrm{X}$ & 2 & 3 & 2 & 16 & 0,143 & 4 & 0,571 \\
\hline & $\mathrm{IF}_{6}$ & 2 & 2 & 2 & 2 & 2 & $\mathrm{X}$ & 3 & 3 & 16 & 0,143 & 3 & 0,429 \\
\hline & $\mathbf{I F}_{7}$ & 2 & 3 & 1 & 1 & 1 & 1 & $\mathrm{X}$ & 1 & 10 & 0,089 & 4 & 0,357 \\
\hline & $\mathrm{IF}_{8}$ & 3 & 3 & 3 & 3 & 2 & 1 & 3 & $\mathrm{X}$ & 18 & 0,161 & 3 & 0,482 \\
\hline \multicolumn{10}{|c|}{ TOTAL } & 112 & 1 & 27 & 3,295 \\
\hline
\end{tabular}

Description:

$1=$ if the horizontal indicator is less important than the vertical indicator

$2=$ if the horizontal and vertical indicators are equally important

$3=$ if the horizontal indicator is more important than the vertical indicator. 
resources, Formation of new village enterprises by involving farmer community groups and breeders. These people take an active role in the progress of the Village as well as a proportionate number of apparatus. Further analysis of external factors can be seen in the following EFE matrix table 2.

Based on the analysis results using an external factor matrix, we obtained a score of 112 with a maximum weight of 1.00 . The highest weight is contained in 4 external factor weights, and the lowest weight is four external factor weights.

The possible score for an organization is 4.00 , with the lowest weight being 1.00 and the average 2.5. A weighted score above 2.5 indicates that the community and the Village respond well to both the aspirations and the results to be achieved by the Village and community. A score below 2.5 indicates that the Village and society are not able to take advantage of existing aspirations to achieve the expected results.

The results of calculations using the EFE matrix show the number 2.981, which means that externally the Village and the Baumata community can carry out and utilize existing aspirations to achieve goals.

Formulation and determination of alternative strategyes in overcoming problems arising from the results of the Village Fund Program Policy Evaluation in Taebenu District, Kupang Regency (study on Baumata Village and Bokong Village, Kupang Regency).

\section{Internal - Eksternal (IE) Matrix Analysis}

Based on the results obtained from the internal factor matrix (IFE) and the external factor matrix (EFE) (Ommani, 2011), then the next step is the Internal-External matrix or IE matrix, where this matrix is used to analyze the position of the Village in more detail and see what strategy is right to be applied to Baumata Village.

Table 3. IE Matrix

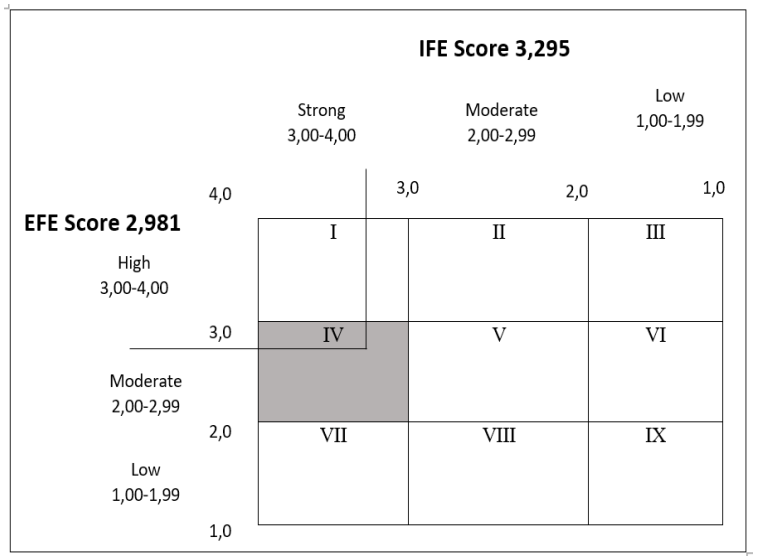

Source: David, 2009 and managed by author, 2020.

The results of the IE as in the picture above with an average IFE value of 3.295 and an average EFE of 2.981 indicating the position of the Village is in the fourth quadrant. In this position, the most appropriate strategy to apply is to grow and build. This alternative is an overview strategy that does not have a technical implementation of the strategy in the Village. Therefore, the SOAR matrix in the form of concrete steps can provide a more detailed description of alternative strategies that should be carried out by the organization.

There are still new problems that arise at the implementation level in the field, so further analysis is needed. In-depth to obtain solutions to overcome these problems. Strength factors include the existence of a budget for development and community empowerment; the existence of a regulation that

Table 2. External Factor Evaluation (EFE) Matrix

\begin{tabular}{|c|c|c|c|c|c|c|c|c|c|c|c|c|c|}
\hline \multirow{2}{*}{\multicolumn{2}{|c|}{$\begin{array}{c}\text { External Factor } \\
\text { EF }_{1}\end{array}$}} & \multicolumn{8}{|c|}{ HORIZONTAL } & \multirow{2}{*}{ Total } & \multirow{2}{*}{ Weight } & \multirow{2}{*}{ Rating } & \multirow{2}{*}{ Scores } \\
\hline & & $\mathrm{EF}_{2}$ & $\mathrm{EF}_{3}$ & $\mathbf{E F}_{4}$ & $\mathbf{E F}_{5}$ & $\mathrm{EF}_{6}$ & $\mathbf{E F}_{7}$ & $\mathrm{EF}_{8}$ & & & & & \\
\hline \multirow{8}{*}{ VERTICAL } & $\mathbf{E F}_{1}$ & $\mathrm{X}$ & 2 & 2 & 1 & 2 & 2 & 2 & 2 & 13 & 0,12 & 4 & 0,481 \\
\hline & $\mathbf{E F}_{2}$ & 2 & $\mathrm{X}$ & 3 & 1 & 3 & 3 & 3 & 2 & 17 & 0,157 & 3 & 0,472 \\
\hline & $\mathbf{E F}_{3}$ & 2 & 1 & $\mathrm{X}$ & 1 & 1 & 3 & 2 & 1 & 11 & 0,102 & 4 & 0,407 \\
\hline & $\mathbf{E F}_{4}$ & 3 & 3 & 3 & $\mathrm{X}$ & 3 & 3 & 3 & 2 & 20 & 0,185 & 2 & 0,370 \\
\hline & $\mathbf{E F}_{5}$ & 2 & 1 & 3 & 1 & $\mathrm{X}$ & 2 & 2 & 1 & 12 & 0,111 & 3 & 0,333 \\
\hline & $\mathbf{E F}_{6}$ & 2 & 1 & 1 & 1 & 2 & $X$ & 1 & 3 & 11 & 0,102 & 3 & 0,306 \\
\hline & $\mathbf{E F}_{7}$ & 1 & 1 & 2 & 1 & 2 & 1 & $\mathrm{X}$ & 1 & 9 & 0,083 & 4 & 0,333 \\
\hline & $\mathbf{E F}_{8}$ & 1 & 2 & 3 & 2 & 3 & 1 & 3 & $X$ & 15 & 0,139 & 2 & 0,278 \\
\hline \multicolumn{10}{|c|}{ TOTAL } & 112 & 1 & 25 & 2,981 \\
\hline
\end{tabular}

Description:

$1=$ if the horizontal indicator is less important than the vertical indicator

$2=$ if the horizontal and vertical indicators are equally important

$3=$ if the horizontal indicator is more important than the vertical indicator. 
regulates the Priority of using the Village Fund in the current year; the existence of human resources who can manage the Village Fund; and the existence of budget allocations for improving the welfare of rural communities through Village enterprises.

Opportunities factors include the existence of budget sources other than the Village Fund that can be used for community development and empowerment; the existence of the implementation of activities that are binding; activities that are oriented towards increasing the existing resources in the Village; and establishment of Village enterprises (Susilowati et al., 2019).

Aspirations factors include the acceleration of development and improvement of village facilities (roads, buildings, public facilities, etc.); strict action against the implementation of activities that do not appropriately run; education and training for resources that manage Village Funds as well as conducting comparative studies to villages that are already included in the category of independent villages; and establishment of Village enterprises by involving farmer groups and livestock groups to improve the welfare of rural communities (suppliers of seeds and sales of produce) (McLean, 2017).

Then the outcome factors to be achieved (results) include the acceleration of development and empowerment of rural communities; proper management of Village Funds following policy expectations; competent resources; and the formation of a new village enterprise by involving farmer and rancher community groups.

In finding alternative solutions to problems that arise as a result of the Policy Evaluation of the Village Fund Program in Taebenu District, Kupang Regency (study on Baumata Village and Bokong Village, Taebenu District), it can be explained more simply as in the SOAR matrix below (Table 4).

\section{Table 4. SOAR Matrix}

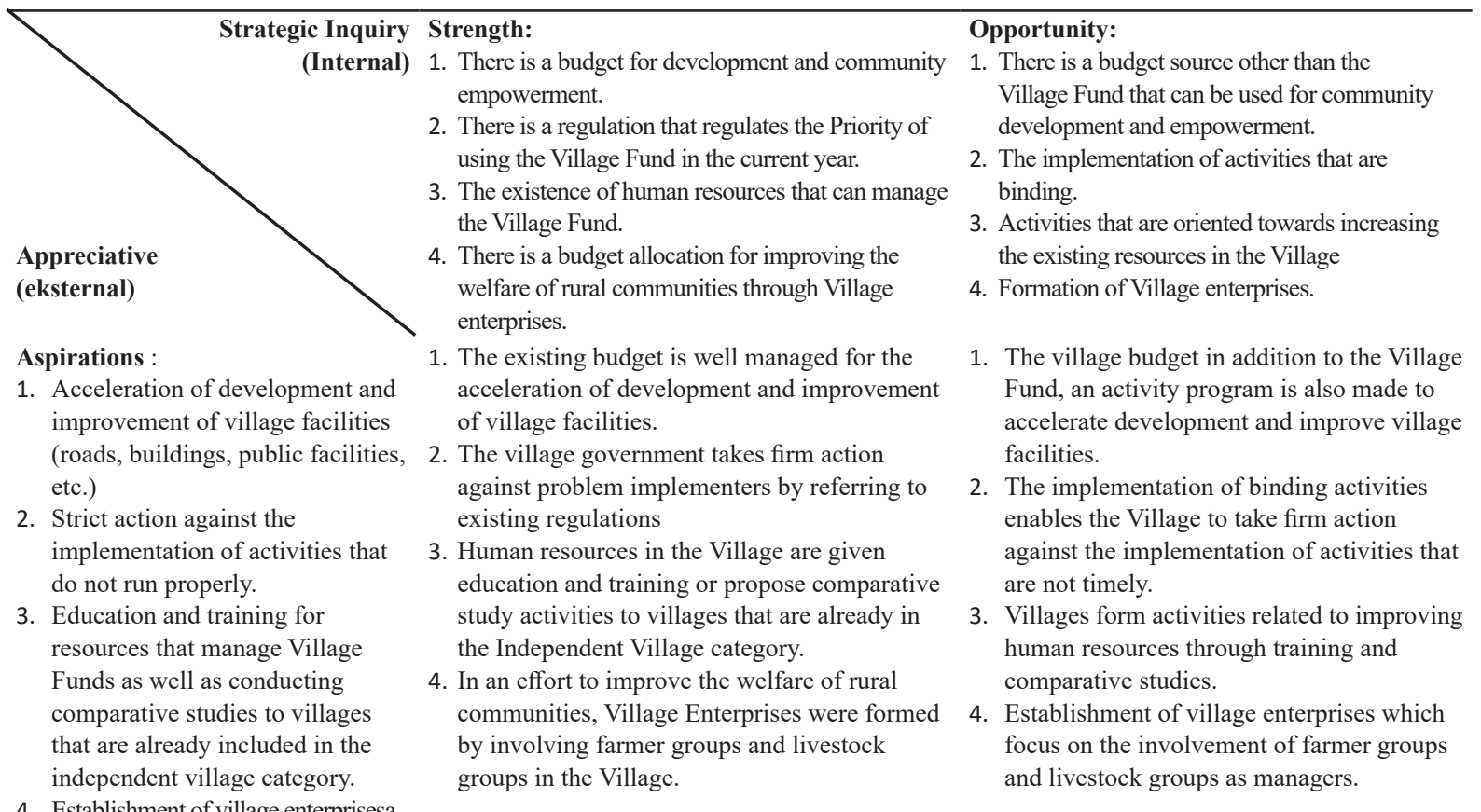

4. Establishment of village enterprisesa by involving farmer groups and livestock groups to improve the welfare of rural communities (suppliers of seeds and sales of produce).

Result :

1. Acceleration of development and empowerment of rural communities.

2. Proper management of Village Funds in accordance with policy expectations.

3. Competent resources.

4. The Establishment of a new village enterprise by involving farmer and rancher community groups.

Opportunity: Village Fund that can be used for community

development and empowerment.

binding.

Activities that are oriented towards increasing the existing resources in the Village

The village budget in addition to the Village Fund, an activity program is also made to accelerate development and improve village

enables the Village to take firm action against the implementation of activities that Vire not timely.

human resources through training and mparative studies. focus on the involvement of farmer groups and livestock groups as managers.
1. The created program focuses on accelerating development and community empowerment.

2. Work based on existing regulations.

3. Existing resources are made activities in order to create competent resources.

4. Village enterprises budget allocation is used to finance businesses in agriculture and animal husbandry.
1. Other budget sources other than village funds are used to accelerate development and empower village communities.

2. Firm action from the government allows the proper use of the Village Fund in accordance with expectations.

3. Establishment of activities related to resource enhancement existing resources to produce competent resources.

4. Establishment of Village enterprises to improve the welfare of the Village Community. 


\section{SA strategy (Strength - Aspiration)}

Starting from research in the field, the authors developed a strategy using the interview method in order to find solutions to problems that occurred in Baumata Village related to the results of the Village Fund Program Policy Evaluation in Taebenu District, Kupang Regency (Studies in Baumata Village and Bokong Village, Taebenu District, Kupang Regency), based on The results of the analysis using the SA (Strength - Aspiration) strategy include, the existing village budget for Village Development and Community Empowerment is utilized according to its designation and on time according to the plan so that the physical construction of roads can be carried out properly and there is an increase in human resources and empowerment activities for increasing community income in the Village; existing regulations make villages have the authority to involve competent village communities in the implementation of activities in the field of village development and community empowerment in the Village (McLean, 2017); and the village budget related to increasing the potential of the village apparatus is used for the implementation of education and training for the village apparatus as well as carrying out comparative studies to independent villages in order to increase the insight and skills of the village apparatus and to trigger the spirit of the apparatus to learn and work harder in order to advance the Village to become an independent village.

\section{SR (Strength - Result) strategy}

Starting from research in the field, the authors developed a strategy using the interview method in order to find solutions to problems that occurred in Baumata Village related to the results of the Village Fund Program Policy Evaluation in Taebenu District, Kupang Regency (Studies in Baumata Village and Bokong Village, Taebenu District, Kupang Regency), based on the results of the analysis using the SR strategy (Strength - Result) include, the existing village development and community empowerment budgets are used correctly and appropriately according to their designation so that the Village has complete access and facilities according to the needs of the village community; existing regulations are binding so that villages can demand and act decisively so that the implementation of village development activities and community empowerment can be carried out in accordance with the targets that have been set; and the available budget for improving the quality of Apparatus Human Resources is included in the priority village activity plans so that the Village has competent and skilled officials in running the government in the Village and managing existing resources.

\section{OA (Opportunities - Aspiration) strategy}

Starting from research in the field, the authors developed a strategy using the interview method to find solutions to problems that occurred in Baumata Village related to the results of the Village Fund Program Policy Evaluation in Taebenu District, Kupang Regency (Studies in Baumata Village and Bokong Village, Taebenu District, Kupang Regency), based on the results of the analysis using the OA (Opportunities - Aspiration) strategy include, budget sources other than the Village Fund are used to maximize road physical development and increase human resources and to create village activity programs that can increase village community income; existing regulations are binding so that the use of village communities in the implementation of village development can be carried out legally and legally and can be sought for implementers in accordance with their respective fields of expertise; and the Village carries out an activity program which brings in sources from outside to carry out education and training for village officials (Anam, 2020).

\section{OR (Opportunities - Result) strategy}

Starting from research in the field, the authors developed a strategy using the interview method in order to find solutions to problems that occurred in Baumata Village related to the results of the Village Fund Program Policy Evaluation in Taebenu District, Kupang Regency (Studies in Baumata Village and Bokong Village, Taebenu District, Kupang Regency), based on the results of the analysis using the OR (Opportunities Result) strategy include, other budget sources in the Village are also used for village development activities and community empowerment such as improving/making facilities and village access so that the Village has access and adequate facilities according to the needs of the village community; binding rules can make the Village take firm action against the implementation of activities in each field that are not running properly so that activities can be carried out in accordance with the activity targets; then the Village carries out activities to optimize the resources of the village apparatus by bringing in resource persons to provide education and training as well as conducting working visits to villages that have been included in the independent village category so that the village apparatus becomes capable and skilled, and motivated in carrying out activities in the Village to advance the Village. 
Starting from the results of the SOAR analysis that has been presented by the author as described above, the researcher tries to formulate alternative strategies that can be considered by Baumata Village in overcoming existing problems based on the results of the Village Fund Program Policy Evaluation in Taebenu District, Kupang Regency (Studies in Baumatan Village and Bokong Village Taebenu District, Kupang Regency), namely:

Strategy 1: The first strategy that needs to be carried out by the Baumata Village government in dealing with problems related to the implementation of the program activities in the field of development and empowerment of rural communities using village funds in 2019 was not carried out according to the targeted time, namely: the existing budget is managed properly to accelerate development and improve facilities village; in addition to the Village Fund, the village budget has also made an activity program to accelerate development and improve village facilities; the programs that are made focus on accelerating development and empowering communities; and other budget sources other than village funds are used to accelerate development and empower village communities.

Strategy 2: the second strategy related to the implementation of activities that are not realized according to the target time so that the work becomes ineffective and efficient, namely the village government takes firm action against the executors of problematic activities with reference to existing regulations; the implementation of binding activities enables the Village to take firm action against the implementation of activities that are not timely; and work based on existing regulations and firm action from the government allows the proper use of the Village Fund in accordance with expectations.

Strategy 3: the third strategy related to the incompetent Village Fund Management Apparatus Resources, namely, human resources in the Village are given education and training or propose comparative study activities to villages that are already in the category of Independent Villages; the Villages establish activities related to improving human resources through training and comparative studies; and existing resources are made into activities to create competent resources and Formation of activities related to increasing existing resources to produce competent resources.

Strategy 4: The fourth strategy related to community welfare is still low, farmer groups and livestock groups have not been utilized to create business entities, namely, in an effort to improve the welfare of rural communities; Village Enterprises are formed by involving existing farmer groups and livestock groups in the Village; establishment of Village enterprises which focus on the involvement of farmer groups and livestock groups as managers; and Village enterprises budget allocation is used to capitalize business in agriculture and animal husbandry sector.

\section{QPSM (Quantitative Strategic Planning Matrix)}

The last stage in proposing a strategy after selecting an alternative strategy is to make a decision to choose what strategy is the most appropriate for the Baumata village government to implement. The QPSM matrix will be used to summarize and evaluate various alternatives objectively based on the previously identified internal and external factors of the organization. QPSM is obtained from the calculation results by multiplying the average weight of each internal and external organizational factor with the AS value (attractiveness score) to obtain a total attractiveness score (TAS). This matrix will produce alternative strategic actions that can be applied by Baumata Village (Table 5).

After conducting the analysis as shown in the table above, the next step is to analyse the results of the data management by ranking the alternative strategies. More details can be seen in the table 6.

\section{Table 6. Strategy Ranking Based on QPSM Matrix Analysis Results}

\begin{tabular}{ccc}
\hline Strategy Alternatives & TAS Score & Rank \\
\hline Alternative 1 & 1,844 & 2 \\
Alternative 2 & 1,804 & 3 \\
Alternative 3 & 1,924 & 1 \\
Alternative 4 & 1,656 & 4 \\
\hline
\end{tabular}

Source: Managed by author, 2020.

The strategy that must be carried out and prioritized by the Baumata Village Government is the third strategy, namely human resources in the Village are given education and training or propose comparative study activities to the Village. already in the category of Independent Village; Villages establish activities related to improving human resources through training and comparative studies; Existing resources are made into activities to create competent resources and Formation of activities related to increasing existing resources to produce competent resources (Susilowati et al., 2019). 


\begin{tabular}{|c|c|c|c|c|c|c|c|c|c|}
\hline \multirow{3}{*}{ Key factors } & \multirow{3}{*}{ Weight } & \multicolumn{8}{|c|}{ Strategy Alternatives } \\
\hline & & \multicolumn{2}{|c|}{ Strategy 1} & \multicolumn{2}{|c|}{ Strategy 2} & \multicolumn{2}{|c|}{ Strategy 3} & \multicolumn{2}{|c|}{ Strategy 4} \\
\hline & & AS & TAS & $\mathbf{A S}$ & TAS & $\mathbf{A S}$ & TAS & $\mathbf{A S}$ & TAS \\
\hline \multicolumn{10}{|l|}{ Strengths } \\
\hline $\begin{array}{l}\text { There is a budget for the field of development and } \\
\text { community empowerment }\end{array}$ & 0,068 & 4 & 0,272 & & & 4 & 0,272 & & \\
\hline $\begin{array}{l}\text { There is a regulation that regulates the Priority of using } \\
\text { the Village Fund in the current year. }\end{array}$ & 0,058 & 4 & 0,232 & 4 & 0,232 & 4 & 0,232 & & \\
\hline $\begin{array}{l}\text { The existence of human resources who can manage the } \\
\text { Village Fund. }\end{array}$ & 0,076 & & & & & 4 & 0,304 & & \\
\hline $\begin{array}{l}\text { There is a budget allocation for improving the welfare } \\
\text { of rural communities through Village enterprises. } \\
\text { Opportunities }\end{array}$ & 0,103 & & & & & & & 4 & 0,412 \\
\hline $\begin{array}{l}\text { The existence of a budget source other than the Village } \\
\text { Fund that can be used for community development and } \\
\text { empowerment. }\end{array}$ & 0,095 & 4 & 0,380 & & & 4 & 0,380 & & \\
\hline There are binding activities. & 0,103 & & & 4 & 0,412 & & & & \\
\hline $\begin{array}{l}\text { Activities that are oriented towards increasing the } \\
\text { existing resources in the Village. }\end{array}$ & 0,058 & & & 4 & 0,232 & 4 & 0,232 & & \\
\hline \multicolumn{10}{|l|}{ Aspirations } \\
\hline $\begin{array}{l}\text { Acceleration of development and improvement of } \\
\text { village facilities (roads, buildings, public facilities, etc.) }\end{array}$ & 0,076 & 4 & 0,304 & & & & & & \\
\hline $\begin{array}{l}\text { Strict action against the implementation of activities } \\
\text { that do not run properly. }\end{array}$ & 0,099 & 4 & 0,396 & 4 & 0,396 & & & & \\
\hline $\begin{array}{l}\text { Education and training for resources that manage } \\
\text { Village Funds as well as conducting comparative } \\
\text { studies to villages that are already included in the } \\
\text { category of independent villages. }\end{array}$ & 0,065 & & & & & 4 & 0,26 & & \\
\hline $\begin{array}{l}\text { Establishment of Village enterprises by involving } \\
\text { farmer groups and livestock groups to improve the } \\
\text { welfare of rural communities (suppliers of seeds and } \\
\text { sales of produce). }\end{array}$ & 0,114 & & & & & & & 4 & 0,456 \\
\hline \multicolumn{10}{|l|}{ Result } \\
\hline $\begin{array}{l}\text { Acceleration of development and empowerment of } \\
\text { rural communities. }\end{array}$ & 0,065 & 4 & 0,260 & & & & & & \\
\hline $\begin{array}{l}\text { Proper management of Village Funds in accordance } \\
\text { with policy expectations. }\end{array}$ & 0,072 & & & 4 & 0,288 & & & & \\
\hline Competent resources. & 0,061 & & & 4 & 0,244 & 4 & 0,244 & & \\
\hline $\begin{array}{l}\text { The Formation of a new Village enterprise by involving } \\
\text { farmer and rancher community groups. }\end{array}$ & 0,087 & & & & & & & 4 & 0,348 \\
\hline Total & & & 1,844 & & 1,804 & & 1,924 & & 1,656 \\
\hline
\end{tabular}

Source: Managed by author, 2020.

For the last alternative strategy that is recommended to Baumata Village is strategy 4, namely, in an effort to improve the welfare of rural communities, Village enterprises are formed by involving farmer groups and livestock groups in the Village; establishment of Village enterprises which focus on the involvement of farmer groups and livestock groups as managers; and Village enterprises budget allocation is used to capitalize business in agriculture and animal husbandry sector.

\section{CONCLUSION}

Strategy in overcoming problems that arise as a result of the Policy Evaluation of the Village Fund Program in Taebenu District (Study in Baumata Village and Bokong Village, Taebenu District, Kupang Regency), then a strategy analysis is carried out using the SOAR (Strength, Opportunity, Aspiration, Result) and QPSM (Strength, Opportunity, Aspiration, Result) methods. Quantitative Strategic Planning Matrix) which is composed of IFE, EFE, IE, SOAR and QPSM matrices. The results obtained are: First, the IFE matrix shows that Baumata Village has a strong strategic opportunity. This is evidenced by the results of the total IFE matrix of 3,295. A score above 2.5 indicates that internally the organization has a stronger strategic opportunity. Second, the EFE matrix shows that the existing aspirations greatly affect Baumata Village, this is evidenced by the total EFE matrix of 2.981. A score above 2.5 indicates that externally, existing aspirations greatly affect the organization. Third, the results of the IFE and EFE matrices are used to construct the IE matrix. The 
IFE matrix value of 3.295 and the EFE matrix value of 2.981 indicate that Baumata Village is in cell IV, which means that in this position the right strategy to use is to grow and build.

Based on the results of the analysis of the organization's internal and external factors, the formulated alternative strategy based on the SOAR matrix, namely the Village Fund Budget is well managed to accelerate development in the Village, firm action on the implementation of problematic activities in accordance with regulations, human resources in the Village are given education and training, Formation of Village enterprises involving farmer groups and livestock groups, Involving all levels of society in every activity in the Village.

\section{REFERENCES}

Accountability Report of the Village Revenue and Expendture Budget Implementation Baumata Village, (2019).

Ali, I. I., Sutarna, I. T., Abdullah, I., Kamaluddin, K., \& Mas'ad, M. (2019). Faktor Penghambat Dan Pendukung Badan Usaha Milik Desa Pada Kawasan Pertambangan Emas Di Sumbawa Barat. Sosiohumaniora, 21(3), 349-354. https://doi.org/10.24198/ sosiohumaniora.v21i3.23464

Anam, C. (2020). Analisis SOAR: Kerangka Berpikir Positif Untuk Menghadapi Tantangan dan Peluang Pendidikan Administrasi Perkantoran Di Era Revolusi Industri 4.0. Pekbis Jurnal, 2(9), 85-94. https://pekbis.ejournal.unri.ac.id/index.php/ JPEB/article/view/7876

Billiocta, Y. (2019). Wakil Bupati Kupang Sebut 129 Kades Belum Laporkan Penggunaan Dana Desa. Merdeka. https://www.merdeka.com/ peristiwa/wakil-bupati-kupang-sebut-129kades-belum-laporkan-penggunaan-danadesa.html

BPS. (2019a). Kabupaten Kupang Dalam Angka.

BPS. (2019b). Kecamatan Tabaenu dalam Angka.

Cole, M. L., Cox, J. D., \& Stavros, J. M. (2018). SOAR as a Mediator of the Relationship Between Emotional Intelligence and Collaboration Among Professionals Working in Teams: Implications for Entrepreneurial Teams. SAGE Open, 8(2). https://doi. org/10.1177/2158244018779109
Cole, M. L., Cox, J. D., \& Stavros, J. M. (2019). Building collaboration in teams through emotional intelligence: Mediation by SOAR (strengths, opportunities, aspirations, and results). Journal of Management and Organization, 25(2), 263-283. https://doi. org/10.1017/jmo.2016.43

David, F. R. (2017). Manajemen Strategi Konsep (7th ed.). Salemba Raya.

Dunn, W. N. (1994). Public Policy Analysis: An Introduction (2nd Editio). Prentice Hall.

Faisal, M. (2018). Implikasi Program Dana Desa Terhadap Kohesi Sosial Di Desa Tamalate Kabupaten Takalar. Sosiohumaniora, 20(3), 222. https://doi.org/10.24198/sosiohumaniora. v20i3.16070

Jahang, B. S. S. (2019). 4.750 anak di Kabupaten Kupang mengalami kekerdilan. Antara News. https://www.antaranews.com/ berita/1008014/4750-anak-di-kabupatenkupang-mengalami-kekerdilan

McLean, G. N. (2017). Will SOAR really help organization development soar? New Horizons in Adult Education and Human Resource Development, 29(1), 25-28. https://doi.org/10.1002/nha3.20168

Ngadisah, N., \& Alma'arif, A. (2019). Peran Dan Fungsi Bumdes Dalam Pembangunan Perdesaan (Studi Pada Desa Bleberan Kecamatan Playen Diy). Jurnal Manajemen Pembangunan, 2(1).

Ommani, A. R. (2011). Strengths, weaknesses, opportunities and threats (SWOT) analysis for farming system businesses management: Case of wheat farmers of Shadervan District, Shoushtar Township, Iran. African Journal of Business Management, 5(22), 9448-9454.

Prabowo, D. (2019). Jokowi Jelaskan Pentingnya Infrastruktur Bagi Indonesia. Kompas. https://properti.kompas.com/ $\mathrm{read} / 2019 / 01 / 15 / 143000221 /$ jokowi-jelaskanpentingnya-infrastruktur-bagi-indonesia

Sprangel, J., Stavros, J., \& Cole, M. (2011). Creating sustainable relationships using the strengths, opportunities, aspirations and results framework, trust, and environmentalism: A research-based case study. International Journal of Training and Development, 15(1), 39-57. https://doi.org/10.1111/j.14682419.2010.00367.x 
Stavros, J. M., \& Malone, P. (2015). Practicing Organization Development. Practicing Organization Development, 285-301. https://doi.org/10.1002/9781119176626
Susilowati, M. W. K., Wahyuningdyah, R. Y., \& Kurniasari, W. (2019). Enhancing the Tourism MSME's Performance Based on SOAR Analysis. 100(Icoi), 330-335. https:// doi.org/10.2991/icoi-19.2019.56 